Brandeis $\mid$ urear

brandeis.edu/j-caste
CASTE: A Global Journal on Social Exclusion

Vol. 2 No. I pp. 97-108

April 2021

ISSN 2639-4928

DOI: $10.26812 /$ caste.v2i1.261

\title{
Indian Media and Caste: of Politics, Portrayals and Beyond
}

\author{
Pranjali Kureel'
}

\begin{abstract}
Media industry in India has witnessed hegemony of dominant castes since its very inception. Such hegemony has had a huge impact on our everyday lives and how we come to experience the world. This paper attempts to analyze how caste operates in the media sector, from its composition to content and argues that Indian media has played a catalytic role in inflicting epistemic violence over the oppressed castes as it helps dominant discourses to prevail and shapes popular perceptions and culture. After going over journalism, the paper examines cinema and television as both- a tool of maintaining the status quo and also as a medium of resistance and assertion. An analysis of the feminist discourse in media reveals a linear and somewhat exclusionary approach that bars the agency of Dalit women from media representation. At the end, it explores the power of the Internet with respect to the emerging Ambedkarite voices that are strengthening a liberatory framework while reclaiming their worldview.
\end{abstract}

\section{Keywords}

Media, caste, gender, news, Bollywood, Ambedkarite

\section{Introduction}

Popularly referred to as the 'fourth pillar of democracy,' media no doubt plays an invaluable role in the investigation of truth and giving a mirror to a society, to a country. The beginnings of Indian media go long back to the eighteenth century when the print media was started in 1780. It was in this year that the first newspaper, 'The Bengal Gazette' was published by James Augustus Hicky. No wonder, in this long journey, the industry has seen a number of transformations and achieved many milestones. However, even within the span of two centuries, one thing that

\footnotetext{
'M.A Student, Dalit \& Tribal Studies and Action, School of Social Work, Tata Institute of Social Sciences, Mumbai

Email: pranjalikureel@gmail.com
}

(C) 202I Pranjali Kureel. This is an open access article distributed under the terms of the Creative Commons Attribution License, which permits unrestricted use, distribution, and reproduction in any medium, provided the original author(s) and source are credited. 
has remained missing, or rather suppressed, in what is called the 'mainstream' media, is the voice of the Dalit.

Dr. Ambedkar had recognized the importance of media and the need for Dalit journalism, which led him to publish the Marathi fortnightly 'Mooknayak' in 1920. Later on, as his journalism and politics evolved to attain the 'freedom of mind'; it would manifest itself in the weekly rechristened as 'Prabuddha Bharat' in the year 1954. The condition of the popular media in his time was a matter of concern to him and he did not shy away from expressing his criticism towards the degrading role of the media. In his famous address delivered in 1943, on the $101^{\text {st }}$ birth anniversary of Mahadev Govind Ranade, Dr. Ambedkar (2014a) put forth a hard-hitting critique of Indian journalism in the following words:

Journalism in India was once a profession. It has now become a trade. It has no more moral function than the manufacture of soap. It does not regard itself as the responsible adviser of the public. To give the news uncolored by any motive, to present a certain view of public policy which it believes to be for the good of the community, to correct and chastise without fear all those, no matter how high, who have chosen a wrong or a barren path, is not regarded by journalism in India its first or foremost duty. To accept a hero and worship him has become its principal duty. Under it, news gives place to sensation, reasoned opinion to unreasoning passion, appeal to the minds of responsible people to appeal to the emotions of the irresponsible ... Never has the interest of country been sacrificed so senselessly for the propagation of hero-worship. Never has hero-worship become so blind as we see it in India today. There are, I am glad to say, honorable exceptions. But they are too few, and their voice is never heard. (Ambedkar, 2014a, p. 227)

Interestingly, what Dr. Ambedkar pointed towards in the above-quoted address is relevant to this very day. It is common knowledge that this so-called pillar of democracy has the capacity to manipulate reality, promote state interests, extend propaganda, or advertise oppressive ideologies. Therefore, to explore this 'other' side of media, it becomes important to investigate the various aspects of it, from its composition and content to how it shapes the popular perceptions. In this paper, I will be exploring the various facets of media around a central theme that, overtly or covertly, plays a major role in this domain - Caste. The aim of the paper is to analyze how caste operates in the domain of media - mainly focusing on journalism, entertainment and advertisement industry, and the social media. In the sections to follow, I will be examining the representation, the nature of content that is produced - how different groups are portrayed and what role it plays in shaping the popular perceptions and culture.

\section{Elephant in the Room: Caste inside the Newsrooms}

It has been noted that media houses that produce stories and content on discriminatory practices, violence and atrocities, often keep the institutional violence and historical injustices existing inside their own offices a hush-hush affair. A report published by Oxfam and Newslaundary (2019) revealed some (not so) surprising numbers exposing casteism that runs in the media industry. Published under the title - Who Tells Our 
Stories Matters: representation of marginalized caste groups in Indian newsrooms, it revealed that out of the 121 leadership positions in the newsroom, including that of editor-in-chief, managing editor, executive editor, bureau chief, input/output editor across the newspapers, TV news channels, news websites, and magazines, none was occupied by a person belonging to Scheduled caste (SC), Scheduled tribes (ST) or other backward class (OBC) communities, whereas 106 were occupied by those belonging to the 'general category'. Few other highlights from this report are as follows:

- Three out of every four flagship debate anchors - were upper castes. Not even one belonged to the Dalit, Adivasi (indigenous), or OBC communities.

- For over 70 percent of their flagship debate shows, a majority of the panelists were drawn from the upper castes by the news channels.

- Only 10 of the 972 articles featuring on the cover pages of the 12 studied magazines were about issues related to caste.

Another survey report brought to fore stark challenges faced by the journalists belonging to SC, ST and OBC communities in the English language media (Harad, 2020). It talked about the experiences of othering, isolation, and discrimination faced by employees from the marginalized communities in the newsrooms where a large majority of employees belong to the 'upper' castes. It brought attention to the caste nexus, which is an invaluable part of their social capital that benefits the so-called upper castes in gaining positions and maintaining caste-exclusive media houses. Moreover, the very minuscule number of journalists from marginalized communities prevents, to a great extent, their organization and makes it difficult to challenge the discrimination and cultural bias that they face in these spaces (Ibid).

This gross overrepresentation of the 'upper' castes in the media houses can be attributed to the historical oppression of the 'lower' castes by the 'upper castes'. While blatant caste-based discrimination is a reality in India to this very day, there are other ways in which caste manifests itself in these spaces that go unrecognized. The point is that this exclusion does not begin to happen in the media houses at the time of employing, rather it is a historical burden of 3000 years that the marginalized bear since their very birth! In 2017, an article published in Al Jazeera pointed towards the Brahminical nature of media colleges, where Brahmin-savarna students far outnumber those from the Dalit, Bahujan, and Adivasi communities. While reserved seats often go unclaimed, the students who do manage to get inside colleges like ACJ (Asian College of Journalism) face extreme alienation and even hostility towards any 'affirmative action,' many times forcing them to either drop out or keep their identity hidden to prevent the negative consequences (Mondal, 2017).

The constitution of India extends representation to the SC, ST and OBC communities in the government institutions according to their population size. However, media institutions, being privately owned, are not required to implement the policy of reservations, and they haven't reflected on voluntarily extending affirmative action to ensure the presence of people from the marginalized communities. While the reservation policy is not implemented, advertisements for vacancies too rarely make it to the public domain (Ibid). Moreover, these privately owned media houses are often controlled by extended families (Anand, 2005). As a result, the positions are largely filled on the basis of connections and networks. The so-called upper castes end up 
benefitting from the social and culture capital that is accumulated over generations inherited by them. It is very rare for Dalit, Bahujan, or Adivasi individuals to get access to these networks which are exclusionary by their very nature. Hence, the stories of the oppressed are told by the oppressors- reproducing the very social structures they often claim to fight!

\section{Content around Caste and its Impact}

As human beings remain a part of the society that they see and engage with, their location in the structures that exist in the society plays a significant role in how they perceive reality and more importantly, how they arrive at knowledge. As observed in the above section, a large majority of positions in the media houses is occupied by social groups that are above the oppressed population in the caste hierarchy. The oppressor castes that are actually a numerical minority end up producing stories and reporting news on the marginalized population. As a result, as has been noted by many anti-caste individuals, the stories produced by media reflect a casteist mindset in one way or the other.

First of all, issues of caste are reported less or largely ignored by the media. While many times, the issue of caste is consciously concealed in the news reports. As the Oxfam and Newslaundary survey also revealed, merely 10 of the 972 articles that appeared on the cover pages of 12 magazines under study addressed caste related issues. While no media house was interested in covering any caste-based atrocities due to lack of readership for the said issues a decade ago, the amount of reportage on the same has increased in the recent years. The reason for this change in course is attributed to the rise of the so-called 'alternate' media outlets run by editors of marginalized communities (Mondal, 2017). These media houses are reporting from the grass roots and have managed to attract readers/viewers for the stories and experiences they bring out in the open. However, even though the caste atrocities and such cases are being covered at least more than how it was a decade ago, there is still a long way to go for the media houses to practice honest and meaningful journalism.

A very important second point that needs to be made here is regarding the nature of content that is produced by the 'mainstream' media. Many a times, it has been found that even though stories on caste and media coverage of atrocities etc. are done by journalists, their biases almost always come in their work. For example, while journalists fly down to villages to report the details of the caste atrocities, all their narratives remain one sided - highlighting the oppression and oppressed while completely omitting the other part of the story - the oppressor. Dalit people, whose faces are often not even blurred, are treated as if they are just objects of what is called the 'victim porn.' S. Anand (2005) names this biased reporting 'Visible Dalit, invisible Brahmin' where covering caste is equated with writing only about Dalits, mostly located in the rural areas - their experiences, their social condition, atrocities such as murders, rapes, etc. These irresponsible biased narratives have kept the oppressorsthe Brahmin-Dwija ${ }^{1}$ communities away from the eye of scrutiny due to which their caste conditioning and pride rarely comes to be questioned.

\footnotetext{
${ }^{1}$ In the caste system the top three castes - Brahmins, Kshatriyas and Vaishya- are called Dwija or twice born, the second birth of the boy being marked at the time of his scared thread wearing ceremony. The lower castes are not allowed to wear the sacred thread.
} 
The recent Hathras atrocity, in which a woman belonging to a Dalit community was raped and murdered by the Thakur (upper caste) men of Hathras village in Uttar Pradesh, got considerably wide coverage by media. With journalists conversing with Ambedkarite leaders and feminists such as Kiruba Munusamy, Riya Singh, Divya Malhari etc., one could hear their strong voice coming to the forefront through news channels and webinars- which is of course a welcome change although one must keep in mind that caste atrocities remain grossly underreported. Moreover, after all the cases of atrocities against the Dalit community, rarely has media tried entering the settlements of the so-called upper castes and tried to investigate how caste plays a role in their world, and examined the mind that perpetrates such heinous crimes. In the afore-mentioned Hathras atrocity, for instance, the Thakur caste, which is a dominant caste in the northern Uttar Pradesh state with a history of inflicting atrocities on Dalits, did not come under the scrutiny of media as much. This has been the case with about all the media reporting on caste-based atrocities. This practice of understanding caste issues as only 'Dalit issues' is detrimental to the anti-caste struggle as the image of the 'Dalit' keeps on getting reproduced as the victim, while the oppressor castes and their caste pride do not come to be questioned. Dr. Ambedkar (2014b, p. 3) had grasped this attitude on the part of the upper castes engaging with caste issues in the following words:

It is usual to hear all those who feel moved by the deplorable condition of the Untouchables unburden themselves by uttering the cry "We must do something for the Untouchables". One seldom hears any of the persons interested in the problem saying 'Let us do something to change the Touchable Hindu'. It is invariably assumed that the object to be reclaimed is the Untouchables.

Another equally, if not more, detrimental consequence of such journalism has been that it has contributed in reducing the issue of caste to merely a rural problem. In the name of reporting caste issues, journalists reach villages to cover the atrocities but fail to see Brahminical hegemony in the urban spaces. S. Anand's (2005) critique of P. Sainath's reportage highlights this issue. Sainath is a prominent Brahmin journalist and a role model for many aspiring journalists. He fetched the Amnesty International Award 2000 for his piece A Dalit Goes to Court. Anand (2005, p. 184) notes:

Sainath's style of 'rural reporting' and 'developmental journalism' does mention the occasional brahmin block development officer, but precludes the scope of discussing the preponderance of brahmins and other savarnas (similar-ranked castes) in, say, Jawaharlal Nehru University's (JNU) history or economics department or on the editorial staff of The Hindu, The Hindustan Times, or The Times of India. Such journalism does not see caste discrimination when historian Romila Thapar or economist Prabhat Patnaik does not find a single 'competent' Dalit or Adivasi candidate to fill the constitutionally stipulated quota of 22.5 per cent in their respective departments, but points us merely to caste discrimination in rural panchayats where Dalits are not allowed to contest for democratically elected posts or are not allowed to function freely even if elected.

Such practices of media persons which include doing stories on Dalit and Adivasi bodies and winning awards and adulation them point towards their tendency to capitalize on the marginalized people's experiences. This becomes especially apparent when taken into account the negligible representation and even hostility towards 
journalists who come from marginalized communities. It suggests how caste comes at play, be it in media or academia, where it is always the dominant producing knowledge on the dominated, and never the vice-versa. In this structure, the dominated is ripped off of their epistemic capacities, and turned into bodies/objects without any thinking capacity- for the dominant to reflect upon (Guru, 2002).

Like the absent coverage of 'caste issues' in the oppressor's world, another thing that does not meet the eye of the mainstream media is the culture of knowledge and assertion of Ambedkarites. Dr. Ambedkar's birth anniversary as Ambedkar Jayanti and his death anniversary as Mahaparinirvana divas are observed all over India and in the diaspora. Hundreds of thousands of people gather at Chaityabhoomi ${ }^{2}$ in Mumbai; books, especially powerful Dalit literature, worth millions of rupees are bought by people on these days. Similarly, on Dhamma Chakra Parivartan Divas ${ }^{3}$, which is observed every year to commemorate the revolutionary step that Dr. Ambedkar took in the liberation of Dalits - conversion to Buddhism. Many Dalits free themselves from the Brahminical framework by embracing Buddha Dhamma Sangha. Every year, hundreds of thousands of Ambedkarite Buddhists gather at Deekshabhoomi ${ }^{4}$ on this day. Mainstream media, however, being dominated by the so-called upper caste Hindus keep boycotting these events. This cultural hegemony of the upper-caste Hindus in the industry translates to media writing, talking and doing programmes on religious festivals like Karva Chauth, Lohri, Dhana Laxmi etc., but a complete silence around birth anniversary of Ambedkar and that of saints like Valmiki or Ravidas who belonged to oppressed communities (Kumar, 2005). Such cultural invisiblization of the marginalized and minority groups from mainstream media adds to the said hegemony of the upper-caste Hindu. This issue will be dealt in more detail in the subsequent sections.

The battle of Bhima Koregaon in which 500 Mahar (ex-untouchable caste) soldiers under the British Army defeated the Peshwa Army of approximately 30,000 is celebrated by Dalits every year on January one. This war is seen as a historical event that marks the victory of the oppressed over their oppressors. In the year 2018, these celebrations were disrupted, followed by violence and then arrest of Dalit activists on the account of 'anti-nationalist' activities. The bias of mainstream media around this time became very evident when it did not cover the initial celebration that took place, but only started reporting when Dalits protested against the violence unleashed by the caste supremacists (Mhaskar, 2018). The attack of caste supremacists on the peaceful celebration and the issue of unjust arrests of Dalit activists hasn't been seen being raised on the news channels as well as newspapers. Another pertinent question that arises here is why is a proud event for Dalit groups not recognized and shown as part of the 'Indian History?'

\section{Cinema and Television: Pop Culture and the Politics of Portrayal}

It is popularly believed that 'films are a reflection of the society,' and less popularly is the role of films and television recognized in how they construct the social reality

\footnotetext{
${ }^{2}$ The memorial to Dr. B.R. Ambedkar where his cremation was performed.

${ }^{3}$ This is the day to celebrate the conversion of Dr. Ambedkar and his approximately 600,000 followers to Buddhism on 14 October 1956 in Nagpur.

${ }^{4}$ The site or ground here Dr Ambedkar and his followers embraced Buddhism.
} 
itself. For one thing, it is first of all important to establish that those who make films, TV shows, write those stories, put life in the characters, etc. are not removed from the society. The creators themselves have a certain location in the society, see the world from that location, and of course hold certain biases that find their way into the content that is produced. Therefore, it would not be wise to assume that films and TV shows give us an 'objective' representation of the reality when what they actually represent is the world view of the creator itself! What is even more important to understand is the role that mass media plays in popularizing the ideas and strengthening discourses that benefit those who hold power in the society.

While there has been a dominance of Brahmin-Dwija castes in the entertainment industry, for decades have their films and television shows- especially the Hindi daily soap operas capitalized on while advancing the Brahminical patriarchal culture. That is how we witness a cultural hegemony of Hindu upper-castes over the mainstream media. Their society, customs, lifestyle appear to be the hallmark of 'Indianness,' while evoking a utopia that acts as an escape for the Dalit-Bahujan masses (Yengde, 2018). Consequently, we are presented with a Hindu upper-caste protagonist as a 'hero'/'savior;' Dalits, Adivasis on the sidelines or victims; Muslims as 'gangsters' and so on. This is also how the term 'Bhartiya Naari' (The Indian woman) invokes an image of what is essentially a Hindu upper caste woman wearing sindoor (vermilion), bindi, jewelry and zari saree in the popular imagination. Not only has TV and cinema invisiblized the culture of Dalit, Bahujan, Adivasis, it also inferiorized it - mainly by glorifying the Hindu savarna culture that the Dalit Bahujan are to aspire to, and never the vice-versa.

This phenomenon can also be understood from the post-structural view that culture consists of the meanings that its subjects produce and reproduce (Belsey, 2002). Although in the context of India, the establishment of control over meanings to gain power goes back to over 3000 years ago! As Mani (2014) points out, Brahmins established themselves in the superior most position in the society by monopolizing over the 'shabd shakti' (power of word), knowing that those who control words and so, their meanings - control the world. Brahmins produced a vast body of literature to institutionalize the most brutal system of discrimination by this control of meanings. There are many sociological studies that show how language imposes the power structures in our everyday life (Ibid, pp. 184-194). Today, media plays a very important role in reproducing the meanings that carry with them the notions of superiority and inferiority through words and symbols. Moreover, it also plays a big role in legitimizing and normalizing Brahminical knowledge. In one of the earliest films created in the history of Indian cinema, Shri Krishna Janma (1918), one can witness an explicit invocation of varnashramadharma through the film. Directed by D.G. Phalke (after whom the highest cinema award-Dadasaheb Phalke Award is named), a part of this film shows frames of 'Brahmin devotee,' 'Kshatriya devotee,' 'Vaishya devotee' and 'Shudra devotee' offering prayers to the Hindu god Krishna.

In the history of Indian cinema, the question of caste has largely been kept concealed behind the categories of poor/or 'comon man'/ or the hard toiling Indian - For example, Awara (1951), Naya Daur (1957), Hum Hindustani (1960), followed by those from the decade of the 1970s - Gopi (1970), Zanjeer (1973), Roti Kapada Aur Makaan (1974), Deewar (1975), Parvarish (1977), Khoon Pasina (1977), Kaala Patthar (1979) (Yengde, 2018). As a result, instead of challenging the institution of caste, the film industry went on to invisiblized the question of caste itself, normalizing 
it to a great extent. In this way, it has largely served the status quo. Maitreya (2020), while laying down the context for the angry young man of the 1970s, noted that it was an on-screen manifestation of the anger possessed by the Dalit Panthers in real life. Yet, it was portrayed through savarna characters, titillating the imagination of the masses and making a national hero, all the while erasing the history behind the anger.

However, that does not mean that never did Bollywood attempt to engage critically with the question of caste. Films such as Sujata (1959), Ankur (1974), Diksha (1991), Bandit Queen (1994); and most recently, Article 15 (2019) have attempted to bring out alternate narratives around caste and to deliver the social message to audience. However, many of such films usually fail to move beyond a convenient view of caste / a savarna gaze - that either victimizes the marginalized population or romanticizes their struggle instead of honestly and ethically engaging with the matter at hand.

This discussion will be incomplete and pointless without mentioning the strongly emerging anti-caste discourse in the domain of cinema. It is, thus, important to discuss the notable work of directors such as Nagraj Manjule, Neeraj Ghaiwan and Pa Ranjith. Manjule's Fandry (2013) and Sairat (2016) and Ghaiwan's Masaan (2015) that not only presented the stark social reality on the big screen, but they did so from an epistemological standpoint of the oppressed themselves. As the stories are drawn from the story teller's own life experiences, they also resonate with the Dalit community whose reactions say 'We have been through this' (Yengde, 2018). On the other hand, Pa Ranjith's Kaala (2018) directly challenges the status quo advanced by a casteist media for a long time - of victim and saviour. Produced by Ranjith's production house, Neelam productions is another YouTube short film titled The Discreet Charm of the Savarnas (2020) that deserves a mention. The most significant thing about Ranjith's content is that it reverses the very gaze that has victimized Dalits for centuries of cinema. They provide a worldview of the Dalits while the characters are assertive, and at the same time, having ownership of their subjectivity. As we have noted the role that media plays in the social and cultural transformation, such films are a step towards exiting the imposed Brahminical construction of reality. However, mainstream Bollywood still has a long way to go.

\section{Caste, Gender and the Media Lens}

Even though 'caste' as a subject may not have been very overt or 'out in the open' in TV programmes and mainstream films, it does not mean that caste culture has not been reinforced through the said medium. As noted in the above section, media industry plays a crucial role in reinforcing Brahminical-patriarchal cultural values and norms. First of all, it is important to iterate here that the institutions of caste and patriarchy are not binary or separate from each other. Brahminical patriarchy is not a patriarchy exclusive of or by the Brahmins, but it 'includes in its very conceptualization that all individuals are allotted a particular position of privilege and deprivation, and the resultant violence and discrimination to the lower caste groups' (Arya, 2020, pp. 217 228). Where control over the woman's body becomes necessary for maintaining the caste boundaries, caste issue and gender issue remain no longer separate from each other. Nor should patriarchal relations be seen in isolation i.e. in the binaries of men oppressing women, when Dalit men themselves are emasculated in the caste society and are oppressed by all 'upper-castes' including savarna women (Ibid).

This deliberation becomes more apparent on examining the concept of 'honor' in TV and cinema. It can be seen in the characterization of the 'pure, ideal' upper- 
caste woman who conforms to the social values and behavioral norms, as against the "loose" woman who may display her sexual agency and freedom. Such a binary, which is very evident especially in the Hindi TV serials, tends to normalize gender roles and even glorify the unpaid labor and struggles of women. Moreover, we get to witness an 'alpha male' savior- who is an embodiment of characteristics that are deemed virtuous in a man. It is essentially a (hyper) masculine, upper-caste patriotic hero who 'protects' those who are supposedly lesser endowed than him which includes 'his woman' or helpless masses. Gupte (2013) argues that in the caste society, the honor of caste groups is tied to the behavior of women which allows men to dictate the 'appropriate behavior' for them and especially command over their sexual agency and desires. She further points out that unlike upper-caste men all women along with lower-caste men do not possess the intrinsic honor, while the nomenclature itself becomes synonymous with their 'lower' status (Ibid). Such media representation, therefore, when looked at from a lens of caste and gender reveals the operation of Brahminical patriarchy in social relations and how it keeps deriving legitimacy through it.

Art is political. More importantly, it can act as a very crucial medium of social transformation. As the famous dialogue of the film Party (1984) goes, 'Every creation of art, through which you are able to concur with the public opinion is a weapon in social and political struggle.' It is true that the entertainment industry has produced some empowering films with strong female leads with agency and sexual freedom. In the recent times cases in point being English Vinglish (2016), Queen (2014), Pink (2016), Veere Di Wedding (2018), etc. While these films have been successful in dodging the male gaze and breaking stereotypes associated with women to a great extent, the representation of this so-called progressive 'modern Indian woman' has remained limited to Brahmin-Dwija women only. Indian cinema has been exclusionary towards Dalit women, who find neither themselves nor their issues represented in these supposedly women-centric films. The mainstream feminist discourse in India has sidelined the issues and frame of reference of Dalit women. Crossing the boundaries of home to go outside to work, and/or getting out of the traditional 'ghoonghat' (veil) and into modern clothing are two of the empowering acts that media presents to us. However, such an approach tends to be quite linear in its course and consequently misses out on varied aspects to the issue. For instance, it invisiblizes Dalit women who, historically (a). have been outside their homes to work in fields/streets/workplaces; and (b) have had to struggle to keep their bodies covered in the caste society. ${ }^{5}$

Ilaiah (2002) points out the cultural differences between the dominant Hindu castes and the Dalit Bahujan population in terms of gender relations. Such a distinction is also reflected in Pa Ranjith's Kaala (2018) where we see assertive marginalized women characters in Dharavi as opposed to the situation in Hari Dada's Brahmin Hindu household. Ilaiah also notes that their books that told stories about women getting $s a t i,{ }^{6}$ did not tell any stories of Dalit Bahujan women who lived after their husbands' deaths, or got divorced, remarried, and worked to earn a living. Another thing to note is the way entertainment industry, advertisements, social media pages, etc. portray 'sexual subjectification' and 'sexual autonomy' as a form of empowerment. Gill (2007) notes that midriff advertising by media adds another layer of oppression by re-sexualizing the woman's body while portraying this new objectification as pleasurable and 'self-

${ }^{5}$ Nangeli and the Channar revolt tell the story of Dalit women fighting against the oppressive laws like breast tax and their struggle for the right to cover their upper bodies.

${ }^{6}$ The practice of widow-immolation at her husband's funeral pyre. 
chosen.' In the Indian context, such representation also reproduces certain savarnabeauty standards i.e. fair skinned, tall, and thin body that is deemed as 'desirable.' The dialogue of the film Bajrangi Bhaijan (2015)- 'doodh jaisi gori hai, zaroor Brahmin hogi' which translates to 'she is as fair as milk, must be a Brahmin' is indicative of such a standard. Those who are excluded from this supposedly empowering representation are not only Dalit women, but also trans-women, disabled women, or dark-skinned women. Moreover, as Gupte (2013) notes, caste and gender hierarchy creates a distinction between the dominant and the subordinate woman, in which it is the dominant woman's asexuality [perceived as 'purity'] that sets her apart from the sexualized [and hence, 'available'] lower woman. The body politic concerning the portrayed 'sexual freedom' does not take into account the issues emanating from the triple burden of caste, class, and gender that Dalit women experience. Caste, sexuality, and labor are connected in ways that have led to women from certain communities performing different types of sexualized labor and availability of this labor in the public domain (Gopal, 2012). The 'empowering' media portrayals, therefore, when analyzed from the location of a Dalit woman reveal the linear and exclusionary course that mainstream feminist discourse tends to take, reducing intersectionality to a mere lip-service. The point here is that the agency of Dalit woman has been missing from media representations. Dalit women have been speaking up and fighting for centuries, as opposed to the stereotypes attached to them that either portray them as evil kutnis (vamps) or powerless victims (Gupta, 2007). Yet, due to the structural inequalities and epistemic violence, they have been reduced to mere objects of others' gaze and never the subject taking ownership of their characters, especially in media projections.

Even on examining the representation of Dalit women within the domain of anti-caste cinema, consisting of films such as Masaan (2015), Sairat (2016), Fandry (2013), Periyerum Perumal (2018), Kaala (2018), etc, we find a similar story. Most of the films, with some exception, have focused on inter-caste love, strictly from a Dalit man's perspective. Further, it is usually a fair-skinned upper caste woman that the Dalit man falls in love with and desires. ${ }^{7}$ While being a breakthrough in Indian cinema, it won't be wrong to say that most of the films with anti-caste discourse, too, have failed to be inclusive of the world-view of Dalit women, their subjectivity, their desires, and doing justice to their personhood.

\section{The Power of the Internet}

Like almost all the aspects in the Indian society, the entertainment industry too is dominated by networks of upper-caste (across religions) individuals and families with generations worth of accumulated privileges and social capital. Getting established in such an industry, which has unofficially been reserved for the said privileged groups since its beginning, takes a lot more than talent and skills. In the recent years, the nepotism debate has brought ripples in the industry, however, there has not been any talk around what lies at the bottom of nepotism- the caste privilege!

While directors like Ghaywan and $\mathrm{Pa}$ Ranjith are actively building conversations around caste and bringing anti-caste discourse in the industry, there is still a lot more that has to be done. Meanwhile, the accessibility and reach of social media has provided an arena of expression and assertion for the marginalized population. Platforms such as YouTube and Instagram have turned out to be quite fruitful for the Ambedkarite

${ }^{7}$ As noted by Padmini Rajora in a Facebook post. 
movement. Artists and creators like The Casteless Collective, Neelam Productions, Somnath Waghmare, Sumeet Samos, and many other artists have been asserting Ambedkarite voices and building an anti-caste discourse through the medium. Social media has also played a significant role in making Ambedkarite Shahirs ${ }^{8}$ into the households of a large population. The recently banned app (on the account of conflict with China), Tiktok had been very popular with the marginalized population who used it to express themselves and also gain a good amount of 'following'. Apart from that, the app was also popular among the Ambedkarite youth in building an online social movement. They did it through creating awareness against religious superstitions and mental slavery and used it as a tool to register dissent, voice their opinions and showcase their ideology and narratives in creative ways (Chaudhari, 2020).

It is true that social media can be a difficult space for an oppressed population, especially one which has historically faced nothing but violence and hate. However, history is also witness to the fact that this population has resisted the oppression, fought and asserted its being, against all odds. Social media plays a catalytic role as Ambedkarite people claim their agency here, which has also been helpful in bringing out liberating narratives and discourses from a freeing framework.

\section{Conclusion}

Be it the newsroom or the entertainment industry- there has been hegemony of the historically oppressor castes in the domain of media. Such hegemony has of course had bearings on the content that is produced by the industry. More so, this content is not an objective representation of the social reality and plays a significant role in producing meanings, discourses and cultures. One thing that becomes clear is that the 'Dalit' has largely remained an object for the oppressor's subjectivity which has failed to turn the gaze inwards to address the question of caste. However, in the present time, we are also witnessing Ambedkarites asserting their voices actively through the medium, especially social media, bringing about an ontological transformation!

\section{References}

Ambedkar, B. R. (2014a). Ranade, Gandhi and Jinnah. In V. Moon(Ed.), Dr. Babasaheb Ambedkar: writings and speeches, vol. 1 (pp. 205-240). New Delhi: Dr. Ambedkar Foundation.

Ambedkar, B. R. (2014b). Untouchables or the children of India's ghetto. In V. Moon (Ed.), Dr. Babasaheb Ambedkar: writings and speeches, vol. 5 (pp. 3-33). New Delhi: Ministry of Social Justice \& Empowerment, Govt. of India.

Anand, S. (2005). Covering caste: visible Dalit, invisible Brahmin. In N. Raj (Ed.), Practising journalism: values, constraints, implications (pp. 172-197). New Delhi: Sage Publications.

Arya, S. (2020). Dalit or Brahmanical patriarchy? rethinking Indian feminism. Caste: A Global Journal of Social Exclusion, 1(1), 217-228.

Belsey, C. (2002). Poststructuralism: A very short introduction. New York: Oxford University Press.

Chaudhari, M. (2020, June 25). Chinese apps, Tiktok and Indian youth. Colourboard, Retrieved on November 12, 2020 from https://www.thecolourboard.com/post/chinese-apps-tiktokand-indian-youth

${ }^{8}$ The term refers to mostly to Ambedkarite poets or lyricists who have used their poetry and songs to protest the caste-system and advocated the establishment of a just society 
Gill, R. (2007). Supersexualize me! advertising and 'the midriffs'. In A. Feona (Ed.), Mainstreaming sex: the sexualization of culture. London: IB Tauris.

Gopal, M. (2012). Caste, sexuality and labour: the troubled connection. Current Sociology, $60(2), 222-238$.

Gupta, C. (2007). Dalit 'viranganas' and reinvention of 1857. Economic and Political Weekly, 42(19), 1739-1745.

Gupte, M. (2013). The concept of honour: caste ideology and patriarchy in rural Maharashtra. Economic and Political Weekly, 48(18), 72-81.

Guru, G. (2002). How egalitarian are the social sciences in India?. Economic and Political Weekly, 37(50), 5003-5009.

Harad, T. (2020). Caste is not a thing of the past: Bahujan stories from the newsroom floor. London: Reuters Institute for the Study of Journalism.

Ilaiah, K. (2002). Why I am not a Hindu: a Sudra critique of Hindutva philosophy, culture and political economy. Kolkata: Samya.

Kumar, R. (2005). Absent Dalit: the Indian newsroom. Exclusion, discrimination, disparity: a symposium on emerging patterns of social inequality in India (Seminar Magazine). Retrieved on November 10, 2020 from https://www.india-seminar.com/2015/672/672 ravish_kumar.htm

Maitreya, Y. (2020). Growing up with Bollywood: Dalit casualties of cinema. In Y. Maitreya (Ed.), Of oppressor's body and mind (pp. 33-43). Nagpur: Panther's Paw Publication.

Mani, B. (2014). Knowledge and power. New Delhi: Manohar Publishers.

Mhaskar, S. (2018, March 20). Violence against Dalits in Maharashtra is not new, but Dalit reaction to it is changing. The Wire, Retrieved on November 10, 2020 from http://dspace. jgu.edu.in:8080/jspui/bitstream/10739/1554/1/Violence\%20Against $\% 20$ Dalits\%20in\%20 Maharashtra\%20Is\%20Not\%20New\%2C\%20but\%20Dalit\%20Reaction\%20to\%20It $\% 20$ Is\%20Changing\%20-\%20Thewire.pdf

Mondal, S. (2017, June 2). Indian media wants Dalit news but not Dalit reporters. Al Jazeera, Retrieved on November 2, 2020 from https://www.aljazeera.com/opinions/2017/6/2/indianmedia-wants-dalit-news-but-not-dalit-reporters/

Phalke, D. (Director) (1918). Shree Krishna Janma [Motion Picture].

Yengde, S. (2018). Dalit cinema. South Asia: Journal of South Asian Studies, 41(3), 503-518. 